\title{
Soil microbial community responding to moderately elevated nitrogen deposition in a Japanese cool temperate forest surrounded by fertilized grasslands
}

Hirohiko Nagano ( $\sim$ nagano.hirohiko@isee.nagoya-u.ac.jp )

Nagoya University https://orcid.org/0000-0002-3090-7709

Masataka Nakayama

Kyoto Daigaku

Genki Katata

Ibaraki University

Keitaro Fukushima

Kyoto Daigaku

Takashi Yamaguchi

Hokkaido Research Organization

Makoto Watanabe

Tokyo Noko Daigaku

Toshiaki Kondo

Kokusai Norin Suisangyo Kenkyu Center

Mariko Atarashi-Andoh

Nihon Genshiryoku Kenkyu Kaihatsu Kiko

Tomohiro Kubota

Ibraki University

Ryunosuke Tateno

Kyoto Daigaku

Jun Koarashi

Nihon Genshiryoku Kenkyu Kaihatsu Kiko

\section{Research Article}

Keywords: Andosol, Forest edge, Moderate nitrogen deposition, Nitrogen mineralization, Nitrification

Posted Date: February 12th, 2021

DOl: https://doi.org/10.21203/rs.3.rs-47616/v2 
License: (c) (i) This work is licensed under a Creative Commons Attribution 4.0 International License. Read Full License

Version of Record: A version of this preprint was published at Soil Science and Plant Nutrition on September 16th, 2021. See the published version at https://doi.org/10.1080/00380768.2021.1974799. 


\section{Abstract}

In order to examine the hypothesis that the soil microbial community in a nitrogen-limited forest responds to moderately elevated nitrogen deposition $\left(<10 \mathrm{~kg} \mathrm{~N} \mathrm{ha}^{-1} \mathrm{yr}^{-1}\right)$, correlations between nitrogen deposition and soil microbial properties were analyzed in a cool temperate forest surrounded by normally fertilized pasture grasslands in northern Japan. Three experimental plots were established in forest edges adjacent to the grasslands and the other three plots were in forest interiors at least $700 \mathrm{~m}$ away from the grasslands. Nitrogen deposition in each plot was measured from May to November 2018. In August 2018, litter and surface soil samples were collected from all plots to measure net nitrogen mineralization and nitrification rates as indicators of microbial activity, and microbial biomass and various gene abundances (i.e., bacterial 16S rRNA, fungal ITS, and bacterial and archaeal amoA genes) as indicators of microbial abundance. Nitrogen deposition in forest edges was 1.4-fold greater than that in forest interiors, whereas maximum deposition was $3.7 \mathrm{~kg} \mathrm{~N} \mathrm{ha}^{-1}$. Nitrogen deposition was significantly correlated with net nitrogen mineralization and nitrification rates and 16S rRNA and bacterial amoA gene abundances. Microbial community structures analyzed for bacterial 16S rRNA and fungal ITS gene amplicons were different between litter and soil samples, but were similar between the forest edge and interior. Nitrogen deposition was also correlated with the soil carbon-to-nitrogen ratio and nitrate and ammonium contents. Thus, it was suggested that some soil microbial activities and abundances in a nitrogen-limited forest likely responded to moderately elevated nitrogen deposition. These findings provide primary information on soil microbial response to moderately elevated nitrogen deposition.

\section{Introduction}

Nitrogen deposition (deposition of nitrate $\left(\mathrm{NO}_{3}{ }^{-}\right)$and ammonium $\left(\mathrm{NH}_{4}{ }^{+}\right)$ions) increased by anthropogenic usage of excess nitrogen fertilizers and fossil fuels (Galloway et al. 2004) is still a major environmental concern in global scale (Decina, Hutyra, and Templer 2019; Dentener et al. 2006; Kanakidou et al. 2016; Reay et al. 2008), while reducing trends in nitrogen deposition are also observed in some areas of Europe and North America as a result of efforts to mitigate anthropogenic nitrogen oxide emissions (Gilliam et al. 2019; Schwede et al. 2018; Waldner et al. 2014). Increased nitrogen deposition variously affects forest ecosystems by altering biodiversity, productivity, biogeochemical cycles, energy dynamics, and so on (Chiwa et al. 2018; Groffman et al. 2018; Janssens et al. 2010; Jia et al. 2020; Reay et al. 2008; Zhang, Chen, and Ruan 2018). These effects of nitrogen deposition on forest ecosystems have been investigated mostly by manipulation experiments with more than $20 \mathrm{~kg} \mathrm{~N} \mathrm{ha}^{-1} \mathrm{yr}^{-1}$ of nitrogen addition (Janssens et al. 2010; Jia et al. 2020; Zhang, Chen, Ruan, 2018). A substantial extent of forest ecosystems over the world is, however, still receiving less than $10 \mathrm{~kg} \mathrm{~N} \mathrm{ha}^{-1} \mathrm{y}^{-1}$ of nitrogen deposition due to limited and heterogeneous distributions of urbanized areas that are receiving extensively elevated nitrogen deposition ( $>20 \mathrm{~kg} \mathrm{~N} \mathrm{ha}^{-1} \mathrm{yr}^{-1}$ ) (Reay et al. 2008; Schwede et al. 2018). Moreover, nitrogen limitations in these forests are expected to occur continuously and broadly because of increased nitrogen demand of forest vegetations under increasing atmospheric $\mathrm{CO}_{2}$ concentrations (Groffman et al. 2018; McLauchlan et al. 2017). Therefore, in order to capture reliable responses of forest ecosystems against 
changing nitrogen status, we need to know more about the effects of moderately elevated nitrogen deposition ( $<10 \mathrm{~kg} \mathrm{~N} \mathrm{ha}^{-1} \mathrm{y}^{-1}$ ) on nitrogen-limited forest ecosystems.

Soil microbial community is an ecosystem component sensitive to changes in nitrogen deposition (Janssens et al. 2010; Niu et al. 2016; Tian et al. 2017; Zhang, Chen, and Ruan 2018; Waldrop, Zak, and Sinsabaugh 2004). In soils amended with extensively elevated nitrogen deposition, $\mathrm{CO}_{2}$ release resulting from microbial decomposition of soil organic matter has generally been reduced (Janssens et al. 2010; Jia et al. 2020; Zhang, Chen, and Ruan 2018). Microbial transformations of inorganic nitrogen compounds, such as nitrification and denitrification, are generally enhanced by nitrogen addition (Niu et al. 2016), increasing the risks of nitrogen leaching into the surrounding water body and emission of nitrous oxide (a greenhouse gas 300-fold more effective than $\mathrm{CO}_{2}$ (IPCC 2013)) to the atmosphere (Butterbach-Bahl, Willibald, and Papem 2002; Niu et al. 2016). In contrast to the microbial responses to extensively elevated nitrogen deposition, Allison et al. [2009] found that fungal species isolated from boreal forest soils responded parabolically to nitrogen addition from 0 to $200 \mu \mathrm{g} \mathrm{N}$. These amounts of added $\mathrm{N}$ were equivalent to only $0.1 \%$ or less of amounts of organic carbon substrates in the soils (Allison et al. 2009). Thus, responses of soil microbial community to moderately elevated nitrogen deposition may differ from the responses against extensively elevated nitrogen deposition. Varied microbial response depending on levels of nitrogen deposition has, however, been less focused in recent meta-analyses examining the effects of nitrogen deposition on soil microbial community (Janssens et al. 2010; Jia et al. 2020; Zhang, Chen, and Ruan 2018).

In the present study, we focused on the relationship between spatially varied nitrogen deposition and soil microbial properties within a cool temperate forest in the eastern area of Hokkaido, Japan. Eastern Hokkaido, including the investigated forest, receives relatively low nitrogen deposition from the atmosphere (2-5 kg N ha-1 $\mathrm{yr}^{-1}$ as a typical value) (Chiwa et al. 2015; Network Center for EANET 2021), while nitrogen deposition in the boundary area of the forest (i.e., forest edge) is possibly more than that in the interior area of the forest (forest interior) owing to advection of nitrogen fertilizer, which was supplied to surrounding pasture grasslands (Fig. 1) (Reinmann and Hutyra 2017; Remy et al. 2016, 2017, 2018a, 2018b). The grasslands surrounding our forest have received normal agricultural management practices, but not extensive fertilization, since after the land reclamation from forest to grassland in the 1950s. Therefore, investigating the relationship between nitrogen deposition and soil microbial properties in the two contrasting areas (forest interior and edge) of this forest would provide primary information on soil microbial responses to moderately elevated nitrogen deposition. In particular, this study was conducted to examine the hypothesis that soil microbial community in a nitrogen-limited forest responds to moderately elevated nitrogen deposition. If the hypothesis is true, soil microbial activities and abundances in a nitrogen-limited forest would change along the spatially varied amount of nitrogen deposition.

\section{Materials And Methods}

\subsection{Site description}


This study was conducted in a natural, deciduous, broad-leaved forest in the Shibecha branch of the Hokkaido Forest Research Station, Field Science Education and Research Center, Kyoto University (N43 ${ }^{\circ}$ 24.2', E144 38.5', $115 \mathrm{~m}$ above sea level) in eastern Hokkaido, northern Japan. The station is registered as an associate site of JaLTER (Shibecha/Shiranuka forest, http://www.jalter.org/en/researchsites/) and is used in a diverse range of ecological research, e.g. (Christopher et al. 2008; Hosokawa et al. 2017; Isobe et al. 2018; Nakayama et al. 2019; Nakayama and Tateno, 2018; Tateno et al. 2019; Urakawa et al. 2014, 2016). Briefly, mean annual air temperature and precipitation for $1981-2010$ were $6.2^{\circ} \mathrm{C}$ and $1169.7 \mathrm{~mm}$, respectively. Growing season is usually from June to October. Season with a persistent snowpack is generally from December to April. Annual maximum snow depth was $64 \mathrm{~cm}$, as an average for 19812010. More detailed features of this forest are given in (Christopher et al. 2008). Pasture grassland surrounding the forest is fertilized with ammonium-rich materials derived from livestock manure and slurry.

\subsection{Establishment of experimental plots}

In May 2018, we established six experimental plots in the forest (Fig. 1a), expecting those plots to have different levels of nitrogen deposition. Three of those plots were located at the forest edge (Edge 1 to 3 ), a boundary between the forest and adjacent pasture grasslands, while the other three were located in the forest interior (Interior 1 to 3 ) at least $700 \mathrm{~m}$ away from the grasslands (Fig. 1a). All experimental plots were $10 \mathrm{~m} \times 40 \mathrm{~m}$ in size. Soils in this forested area have been classified as Andosols, using the classification of the Food and Agriculture Organization (IUSS Working Group WRB, 2015). Dominant vegetations of the plots were natural, deciduous broadleaved trees, mainly Japanese oak (Quercus crispula), with dense understory vegetations of Sasa nipponica. There was no remarkable difference in vegetation status (i.e., species composition, standing tree density and canopy structure) between the forest edge and interior. Briefly, mean diameter at breast height of standing trees was $17.3 \mathrm{~cm}$ throughout the plots. Mean stand density was 829 trees ha-1. Maximum height of Sasa vegetation during the growing season was $80-100 \mathrm{~cm}$.

\subsection{Nitrogen deposition observation}

The amounts of nitrogen deposition in the six experimental plots were measured from May 9th to November 20th, 2018, by continuously collecting throughfall water from the atmosphere to the ground through the canopy vegetation. Seven of shaded plastic buckets equipped with collecting tubes and funnels ( $21 \mathrm{~cm}$ in diameter) were randomly put on each of the experimental plots. Throughfall water was collected by the buckets at an almost bi-weekly interval and then filtered using a $0.45 \mu \mathrm{m}$ pore sized membrane filter (ADVANTEC 25CS045AN, Toyo Roshi Kaisya LTD., Tokyo, Japan). Then, concentrations of $\mathrm{NO}_{3}{ }^{-}$and $\mathrm{NH}_{4}{ }^{+}$were measured using ion chromatography (Dionex-Integrion, Thermo Fisher Scientific, MA, USA). Amount of nitrogen deposition for the individual collection interval was quantified by multiplying the ion concentration in the collected water sample and the amount of throughfall. Then, total amount of nitrogen deposition during the six-month observation period was quantified by summing up the nitrogen deposition for all collection intervals. 


\subsection{Litter and soil sampling}

Litter and surface mineral soil (0-5 cm depth) samples were collected on August 10th, 2018. Three sets of litter and soil samples were collected from each of the experimental plots to obtain the representative mean and the interspatial variation of soil microbial properties within a plot. Here, we determined the locations of litter and soil sampling avoiding areas directly below trees to reduce the possibility of specific effects from roots and rhizospheres on collected samples. Litter samples were collected by gloved hands from an area of $30 \mathrm{~cm} \times 30 \mathrm{~cm}$, which were randomly selected within each of the plot. Soil samples were collected using a shovel. Collected litter and soil samples were cooled and transferred to the laboratory within a day. Soil samples were gently passed through a 4-mm sieve to remove gravel and plant tissues. Litter samples were pieced into a smaller size (ca. less than $2 \mathrm{~mm} \times 2 \mathrm{~mm}$ ) to obtain a homogenized sample. The prepared litter and soil samples were immediately applied to soil microbial analysis. Portions of these samples were air-dried and analyzed for total carbon and nitrogen contents (Koarashi et al. 2018) and pH $\left(\mathrm{H}_{2} \mathrm{O}\right)$, as presented in Table 1. Ammonium and nitrate contents in fresh litter and soil samples (Table 1) were also measured (Urakawa et al. 2014, 2016). All data of soil properties in this study are presented with the unit per area after the conversion with measured bulk density in Table S1. 
Table 1

Chemical properties of litter and soil $(0-5 \mathrm{~cm})$ samples $^{\text {a) }}$ and significance of their correlations with nitrogen deposition ${ }^{b}$ )

\begin{tabular}{|c|c|c|c|c|c|c|c|c|}
\hline \multirow[t]{2}{*}{$\begin{array}{l}\text { Sample } \\
\text { type }\end{array}$} & \multirow[t]{2}{*}{ Property } & \multicolumn{6}{|l|}{$\begin{array}{l}\text { Experimental } \\
\text { plot }\end{array}$} & \multirow{2}{*}{$\begin{array}{l}p \text { value for } \\
\text { correlation } \\
\text { to } \mathrm{N} \\
\text { deposition }\end{array}$} \\
\hline & & Interior 1 & $\begin{array}{l}\text { Interior } \\
2\end{array}$ & $\begin{array}{l}\text { Interior } \\
3\end{array}$ & $\begin{array}{l}\text { Edge } \\
1\end{array}$ & $\begin{array}{l}\text { Edge } \\
2\end{array}$ & $\begin{array}{l}\text { Edge } \\
3\end{array}$ & \\
\hline \multirow[t]{5}{*}{ Litter } & $\begin{array}{l}\text { Total } \\
\text { carbon } \\
{\left[\mathrm{Mg} \mathrm{ha}^{-}\right.} \\
\left.{ }^{1}\right]\end{array}$ & $5.84 \pm 0.26$ & $\begin{array}{l}5.85 \pm \\
0.29\end{array}$ & $\begin{array}{l}5.70 \pm \\
0.63\end{array}$ & $\begin{array}{l}4.19 \\
\pm 0.87\end{array}$ & $\begin{array}{l}3.94 \\
\pm 0.38\end{array}$ & $\begin{array}{l}5.87 \\
\pm 0.12\end{array}$ & 0.14 \\
\hline & $\begin{array}{l}\text { Total } \\
\text { nitrogen } \\
\text { [Mg ha- } \\
\left.{ }^{1}\right]\end{array}$ & $0.30 \pm 0.03$ & $\begin{array}{l}0.30 \pm \\
0.01\end{array}$ & $\begin{array}{l}0.28 \pm \\
0.03\end{array}$ & $\begin{array}{l}0.24 \\
\pm 0.03\end{array}$ & $\begin{array}{l}0.22 \\
\pm 0.04\end{array}$ & $\begin{array}{l}0.34 \\
\pm 0.01\end{array}$ & 0.95 \\
\hline & $\begin{array}{l}\text { Carbon- } \\
\text { to- } \\
\text { nitrogen } \\
\text { ratio }\end{array}$ & $19.74 \pm 0.88$ & $\begin{array}{l}19.63 \\
\pm 0.53\end{array}$ & $\begin{array}{l}20.00 \\
\pm 0.28\end{array}$ & $\begin{array}{l}17.09 \\
\pm 1.48\end{array}$ & $\begin{array}{l}18.51 \\
\pm 1.68\end{array}$ & $\begin{array}{l}17.13 \\
\pm 0.05\end{array}$ & $<0.05, \backslash$ \\
\hline & $\begin{array}{l}\mathrm{NO}_{3}^{-} \\
{\left[\mathrm{kg} \mathrm{N}^{-}\right.} \\
\left.\mathrm{ha}^{-1}\right]\end{array}$ & $0.03 \pm 0.01$ & $\begin{array}{l}0.06 \pm \\
0.07\end{array}$ & $\begin{array}{l}0.04 \pm \\
0.02\end{array}$ & $\begin{array}{l}0.08 \\
\pm 0.02\end{array}$ & $\begin{array}{l}0.10 \\
\pm 0.05\end{array}$ & $\begin{array}{l}0.06 \\
\pm 0.02\end{array}$ & 0.20 \\
\hline & $\begin{array}{l}\mathrm{NH}_{4}^{+} \\
{\left[\mathrm{kg} \mathrm{N}^{+}\right.} \\
\left.\mathrm{ha}^{-1}\right]\end{array}$ & $1.55 \pm 0.29$ & $\begin{array}{l}0.90 \pm \\
0.52\end{array}$ & $\begin{array}{l}0.96 \pm \\
0.41\end{array}$ & $\begin{array}{l}1.20 \\
\pm 0.54\end{array}$ & $\begin{array}{l}0.72 \\
\pm 0.22\end{array}$ & $\begin{array}{l}1.70 \\
\pm 1.07\end{array}$ & 0.46 \\
\hline \multirow[t]{3}{*}{ Soil } & $\begin{array}{l}\text { Total } \\
\text { carbon } \\
\mathrm{Mg} \mathrm{ha}^{-} \\
1]\end{array}$ & $25.84 \pm 3.95$ & $\begin{array}{l}24.23 \\
\pm 2.84\end{array}$ & $\begin{array}{l}25.10 \\
\pm 0.45\end{array}$ & $\begin{array}{l}21.64 \\
\pm 5.39\end{array}$ & $\begin{array}{l}26.83 \\
\pm 0.93\end{array}$ & $\begin{array}{l}27.96 \\
\pm 2.89\end{array}$ & 0.52 \\
\hline & $\begin{array}{l}\text { Total } \\
\text { nitrogen } \\
{\left[\mathrm{Mg} \mathrm{ha}^{-}\right.} \\
1]\end{array}$ & $2.01 \pm 0.28$ & $\begin{array}{l}1.82 \pm \\
0.18\end{array}$ & $\begin{array}{l}1.86 \pm \\
0.10\end{array}$ & $\begin{array}{l}1.77 \\
\pm 0.45\end{array}$ & $\begin{array}{l}2.03 \\
\pm 0.07\end{array}$ & $\begin{array}{l}2.26 \\
\pm 0.27\end{array}$ & 0.17 \\
\hline & $\begin{array}{l}\text { Carbon- } \\
\text { to- } \\
\text { nitrogen } \\
\text { ratio }\end{array}$ & $12.87 \pm 0.42$ & $\begin{array}{l}13.32 \\
\pm 0.27\end{array}$ & $\begin{array}{l}13.54 \\
\pm 0.84\end{array}$ & $\begin{array}{l}12.20 \\
\pm 0.38\end{array}$ & $\begin{array}{l}13.23 \\
\pm 0.52\end{array}$ & $\begin{array}{l}12.40 \\
\pm 0.18\end{array}$ & $<0.05, \searrow$ \\
\hline
\end{tabular}

a) Mean \pm Standard deviation for 3 replicates.

b) $p<0.05$ is defined as the probability level suggesting statistically significant. Upward and downward arrows indicate significantly positive and negative correlations with nitrogen deposition, respectively. 


\begin{tabular}{|c|c|c|c|c|c|c|c|c|}
\hline \multirow[t]{2}{*}{$\begin{array}{l}\text { Sample } \\
\text { type }\end{array}$} & \multirow[t]{2}{*}{ Property } & \multicolumn{6}{|l|}{$\begin{array}{l}\text { Experimental } \\
\text { plot }\end{array}$} & \multirow{2}{*}{$\begin{array}{l}p \text { value for } \\
\text { correlation } \\
\text { to } \mathrm{N} \\
\text { deposition }\end{array}$} \\
\hline & & Interior 1 & $\begin{array}{l}\text { Interior } \\
2\end{array}$ & $\begin{array}{l}\text { Interior } \\
\mathbf{3}\end{array}$ & Edge & $\begin{array}{l}\text { Edge } \\
2\end{array}$ & $\begin{array}{l}\text { Edge } \\
3\end{array}$ & \\
\hline & $\begin{array}{l}\mathrm{NO}_{3}^{-} \\
{\left[\mathrm{kg} \mathrm{N}^{-}\right.} \\
\left.\mathrm{ha}^{-1}\right]\end{array}$ & $0.23 \pm 0.02$ & $\begin{array}{l}0.19 \pm \\
0.12\end{array}$ & $\begin{array}{l}0.27 \pm \\
0.17\end{array}$ & $\begin{array}{l}0.37 \\
\pm 0.15\end{array}$ & $\begin{array}{l}0.51 \\
\pm 0.08\end{array}$ & $\begin{array}{l}0.44 \\
\pm 0.30\end{array}$ & $<0.05, \nearrow$ \\
\hline & $\begin{array}{l}\mathrm{NH}_{4}^{+} \\
{\left[\mathrm{kg} \mathrm{N}^{-}\right.} \\
\left.\mathrm{ha}^{-1}\right]\end{array}$ & $1.62 \pm 0.28$ & $\begin{array}{l}1.33 \pm \\
0.42\end{array}$ & $\begin{array}{l}1.65 \pm \\
0.43\end{array}$ & $\begin{array}{l}0.73 \\
\pm 0.27\end{array}$ & $\begin{array}{l}1.20 \\
\pm 0.68\end{array}$ & $\begin{array}{l}1.00 \\
\pm 0.19\end{array}$ & $<0.05, \searrow$ \\
\hline & $\begin{array}{l}\mathrm{pH} \\
\left(\mathrm{H}_{2} \mathrm{O}\right)\end{array}$ & $5.0 \pm 0.1$ & $\begin{array}{l}4.9 \pm \\
0.3\end{array}$ & $\begin{array}{l}5.3 \pm \\
0.1\end{array}$ & $\begin{array}{l}4.9 \pm \\
0.1\end{array}$ & $\begin{array}{l}4.9 \pm \\
0.2\end{array}$ & $\begin{array}{l}4.9 \pm \\
0.1\end{array}$ & 0.10 \\
\hline \multicolumn{9}{|c|}{ a) Mean \pm Standard deviation for 3 replicates. } \\
\hline \multicolumn{9}{|c|}{$\begin{array}{l}\text { b) } p<0.05 \text { is defined as the probability level suggesting statistically significant. Upward and } \\
\text { downward arrows indicate significantly positive and negative correlations with nitrogen deposition, } \\
\text { respectively. }\end{array}$} \\
\hline
\end{tabular}

\subsection{Analysis of soil microbial property}

Litter and soil samples were also applied to measurements of net nitrogen mineralization and nitrification rates, microbial biomass carbon and nitrogen, and various gene abundances, such as bacterial 16S rRNA, fungal ITS, and bacterial and archaeal amoA genes. Mineralization and nitrification rates were measured as indicators of microbial abundance, and microbial biomass and gene abundance were indicators of microbial abundance. The net nitrogen mineralization and nitrification rates were determined, respectively, as the changes in the concentrations of total inorganic nitrogen $\left(\mathrm{NO}_{3}{ }^{-}+\mathrm{NH}_{4}{ }^{+}\right)$and $\mathrm{NO}_{3}{ }^{-}$ only after aerobic incubation of soils at $25^{\circ} \mathrm{C}$ for 4 weeks (Urakawa et al. 2014, 2016). In the investigated forest, these net mineralization and nitrification rates can be indicative metrics for gross mineralization and nitrification rates, respectively (Urakawa et al. 2016). Moreover, the well-known correlation between nitrogen mineralization rate and microbial $\mathrm{CO}_{2}$ production rate (Haney, Brinton, and Evans 2008; Rustad et al. 2001; Zak et al. 1999) enables us to infer behaviors of organic matter decomposition and consequent $\mathrm{CO}_{2}$ release. Microbial biomass carbon and nitrogen were measured using the chloroform fumigation extraction method (Vance, Brookes, and Jenkinson, 1987). Total DNA was extracted from 0.1 - $0.5 \mathrm{~g}$ of fresh litter and soil samples using a DNeasy Power Soil Kit (Qiagen, Hilden, Germany). Abundances of microbial genes were then quantified with an Illumina's Eco Real-Time PCR System (Illumina, CA, USA) and commercial reagent kits or primer sets targeting specific gene regions. Femto bacterial and fungal DNA quantification kits (Zymo Research, CA, USA) were used for bacterial 16S rRNA and fungal ITS genes. For bacterial and archaeal amoA genes, the primer sets of amoA1f/amoA2 $r$ (Rotthauwe, Witzel, and Liesack 1997) and CrenamoA23f/Cremamo616r (Tourna et al. 2008) were used, 
respectively, with FastStart Essential DNA Green Master (Roche, Basel, Switzerland) as a PCR reaction mixture. The PCR conditions are shown in Table S2.

Microbial community structures in litter and soil samples were also analyzed for bacterial 16S rRNA and fungal ITS gene amplicons using a high-throughput DNA sequencer (MiSeq, Illumina). Due to the limitation of funding ability, DNA samples extracted from Edge 2 and Interior 1 plots were used for this evaluation to briefly capture the difference in the microbial community structure between these two contrasting plots. Interior 1 was located farthest from the surrounding grasslands, while nitrogen deposition at Edge 2 was middle of the three edge plots (Fig. 1). The amplicon libraries of bacterial $16 \mathrm{~S}$ rRNA and fungal ITS genes were prepared using the 16S (V3-V4) Metagenomic Library Construction Kit for NGS (TaKaRa Bio) and the primer set of ITS3-F/ITS4-R (Waud et al. 2014), respectively, in the coupling with the Nextera XT Index Kit (Illumina). A total 0.16 million of $2 \times 250$ bp paired-end reads of bacterial 16S rRNA genes and a total 1.26 million of $2 \times 150$ bp paired-end reads of fungal ITS genes were obtained from 12 total genomic DNA samples ( 2 depths $\times 2$ sites $\times 3$ replications). These sequences were then binned into operational taxonomic units (OTUs) of 1592 for bacterial 16S rRNA genes and 2625 for fungal ITS genes by using CD-HIT-OTU (Li et al. 2012), which were configured with a clustering threshold value of 0.97 and a per-base PCR error value of 0.01 . Taxonomies of the OTUs were determined with Quantitative Insights Into Microbial Ecology (QIIME, an open-source software pipeline for analysis of microbial community sequence data) (Caporaso et al. 2010). In the QIIME analysis, OTU sequences for 16S rRNA and ITS were classified using the RDP classifier (Wang et al. 2007) and the UNITE classifier (Abarenkov et al. 2010), respectively.

\subsection{Statistical analysis}

Statistical analysis in the present study was performed using R software ver. 3.6 (R Core Team 2017). The two-way ANCOVA using glm function in base package (R Core Team, 2017) was applied to examine the significant correlation between nitrogen deposition and soil microbial properties, and also to examine the significant interactive effect of different soil layers (i.e., litter vs. $0-5 \mathrm{~cm}$ soil) on these correlations. The ANCOVA was applied to a total 36 datapoints ( 6 plots $\times 2$ soil layers $\times 3$ replications). The correlation between nitrogen deposition and possibly confounding environmental factors, that is, mean soil water content and temperature for the observation period, was also examined. Soil water content and temperature can vary between forest interior and edge locations due to differences in ecological and meteorological features between forest interiors and edges (Reinmann and Hutyra 2017; Remy et al. $2016,2017,2018 a, 2018 b)$. The correlations between nitrogen deposition and soil chemical properties, i.e., carbon and nitrogen contents, $\mathrm{pH}\left(\mathrm{H}_{2} \mathrm{O}\right)$, and $\mathrm{NO}_{3}{ }^{-}$and $\mathrm{NH}_{4}{ }^{+}$contents, were also examined in order to capture their possible changes associated with moderately elevated nitrogen deposition and microbial properties. The bacterial and fungal community structures were compared among different soil layers and sites with the permutational multivariate analysis of variance (perMANOVA, 9999 random permutations) by adonis function in vegan package (Oksanen et al. 2018). The probability levels suggesting statistical significance (i.e., p values) are defined as 0.05 in the present study. 


\section{Results}

\subsection{Summary of nitrogen deposition}

Cumulative nitrogen deposition via throughfall for the six-month period (from May to November) ranged from 2.2 to $3.7 \mathrm{~kg} \mathrm{~N} \mathrm{ha}^{-1}$ in the six experimental plots (Fig. 1). The maximum and minimum amounts of nitrogen deposition were observed in the most northern plot of the forest edge (Edge 3) and in the most northern plot of the forest interior (Interior 3), respectively. In summary, mean nitrogen deposition for three plots of the forest edge was $3.5 \pm 0.9 \mathrm{~kg} \mathrm{~N} \mathrm{ha}^{-1}$, which was 1.4 -fold higher than that of the forest interior $\left(2.5 \pm 0.7 \mathrm{~kg} \mathrm{~N} \mathrm{ha}^{-1}\right)$. This difference in nitrogen deposition between the forest interiors and edges was considered statistically significant by the t-test. A large proportion $(>76 \%)$ of the nitrogen deposition was in the form of $\mathrm{NH}_{4}^{+}$.

\subsection{Soil microbial properties vs. nitrogen deposition}

Net mineralization and nitrification rates showed positive correlations with nitrogen deposition (Fig. 2). These positive correlations were statistically significant without any significant interactive effects from combinations of soil layer and nitrogen deposition $(p>0.05)$.

Abundances of $16 \mathrm{~S}$ rRNA and bacterial amoA genes showed positive correlations with nitrogen deposition (Fig. 3). The positive correlation between 16S rRNA gene abundance and nitrogen deposition was statistically significant without significant interactive effects from the combinations of soil layer and nitrogen deposition ( $p>0.05$ ). The positive correlation between bacterial amoA gene abundance and nitrogen deposition was also statistically significant, showing a significant interactive effect from the combinations of soil layer and nitrogen deposition. The slope value for the relationship between nitrogen deposition and bacterial amoA gene abundance in the surface mineral soils was 3.5 -fold greater than that in the litter layer. There was no significant correlation between other microbial properties and nitrogen deposition $(p>0.05)$. There was also no significant difference in microbial community structure between Edge 2 and Interior 1, while microbial community structure was significantly different between the litter and soil layers (Fig. 4).

\subsection{Environmental factors vs. nitrogen deposition}

There was no apparent correlation between nitrogen deposition and environmental factors (i.e., temperature and soil water content) (Fig. 5). Comparing mean values of these environmental factors between the forest edge and interior, the differences were only $0.2{ }^{\circ} \mathrm{C}$ in temperature and $1 \%$ in soil water content, without any significant differences by t-test $(p>0.05)$.

\subsection{Soil chemical properties vs. nitrogen deposition}

In contrast to environmental factors, some soil chemical properties were found to be significantly correlated with nitrogen deposition (Table 1). Carbon-to-nitrogen ratios of litter and soil samples were 
negatively correlated with nitrogen deposition. In soil samples, $\mathrm{NO}_{3}{ }^{-}$content showed a positive correlation with nitrogen deposition, while $\mathrm{NH}_{4}{ }^{+}$content showed a negative correlation with nitrogen deposition.

\section{Discussion}

\subsection{Soil microbial activity vs. nitrogen deposition}

Nitrogen disposition was significantly greater in the forest edge than in the forest interior (Fig. 1). Given that $\mathrm{NH}_{4}{ }^{+}$consisted of more than $76 \%$ of the deposited nitrogen and fertilization in surrounding pasture grasslands were conducted with ammonium-rich materials derived from cattle manure and slurry, significant contributions of nitrogen fertilizer from the grasslands to the forest through ammonia volatilization (Hayashi and Yan 2010) were suggested. These amounts of nitrogen deposition in this forest were, however, less than half of the threshold amount, causing adverse effects on temperate and boreal forest ecosystems (i.e., 10-15 kg N ha ${ }^{-1} \mathrm{y}^{-1}$ ) (Bobbink et al. 2010; Nordin et al. 2005). Thus, the bioavailability of nitrogen in the investigated soils in both the interior and edge plots was likely limited.

Soil microbial activity at the forest edge was likely enhanced by moderately elevated nitrogen deposition because significant correlations were found between nitrogen deposition and net mineralization and nitrification rates (Fig. 2). This microbial response is different from observations of the reduction in soil microbial $\mathrm{CO}_{2}$ release in forests under extensively elevated nitrogen deposition (Janssens et al. 2010; Jia et al. 2020; Zhang, Chen, and Ruan 2018). The enhancements of microbial activity and presumably soil organic matter decomposition at our forest edges are partially supported by the observations of the negative correlations between nitrogen deposition and soil carbon-to-nitrogen ratio (Table 1). The relative abundance of carbon to nitrogen in soil organic matter generally decreases with the progress of microbial decomposition, where organic carbon is mineralized to and released as $\mathrm{CO}_{2}$, whereas nitrogen is retained and reutilized by soil microbial community (Koarashi et al. 2015; Kramer, Lajtha, and Aufdenkampe 2017). Correlations between nitrogen deposition and individual content of soil inorganic nitrogen species (Table 1) probably resulted from the enhanced consumption of $\mathrm{NH}_{4}{ }^{+}$and production of $\mathrm{NO}_{3}{ }^{-}$through nitrification under moderately elevated nitrogen deposition (Fig. 2).

Such an enhancement of soil microbial activity under moderately elevated nitrogen deposition (Fig. 2) can contribute to increased $\mathrm{CO}_{2}$ production through decomposition of soil organic matter, thus increasing atmospheric $\mathrm{CO}_{2}$ concentration. Moreover, considering the previously known sensitive responses of microbial processes to nitrogen addition (Allison et al. 2009; Butterbach-Bahl, Willibald, and Papem 2002; Jassal et al. 2011; Niu et al. 2016; Smith et al. 2000), not only the extensive elevation, but also the moderate elevation of nitrogen deposition may significantly alter the soil nutrition dynamics, particularly at forest boundary edge areas.

\subsection{Soil microbial abundances vs. nitrogen deposition}


There was a remarkable difference between bacterial and fungal abundances in terms of their correlations with nitrogen deposition (Fig. 3). This difference between bacteria and fungi is considered to be the reflection of different nitrogen demands between these two different microbial groups (Strickland and Rousk 2010). In general, bacterial biomass is relatively enriched with nitrogen rather than fungal biomass does, suggesting a higher nitrogen demand for the bacterial body (Strickland and Rousk 2010). Therefore, the observed linkage between bacterial abundance and nitrogen deposition is reliable under the assumption of high sensitivity of bacteria to nitrogen availability. These different responses to nitrogen deposition between bacteria and fungi were also inferred from a lower ratio of microbial biomass carbon to nitrogen and a lower ratio of fungal to bacterial gene abundance at forest edges than at forest interiors (Fig. 3), whereas differences in these ratios between the forest edges and interiors were not statistically significant $(p>0.05)$.

The bacterial amoA gene abundance appeared to respond to nitrogen deposition, but the archaeal amoA gene abundance was not (Fig. 3). In the investigated forest, Isobe et al. [2018] also found gross nitrification rate synchronously changing with bacterial amoA gene abundances during winter. These microbial features at our forest site are somewhat different from a previous study finding that archaeal ammonia oxidizers play an important role in the soil nitrification process in temperate forests and agricultural upland soils in Europe (Leininger et al. 2006). One of the possible interpretations for this discrepancy between European and Japanese forest soils is that soil conditions of our forest are preferable for bacterial ammonia oxidizers, which have larger cell bodies and higher cell-specific-unit activity compared with archaeal one (Jia and Conrad 2009). Then, the specific dependence of bacterial ammonia oxidizers on autotrophic growth and contrasting dependence of archaeal oxidizers on heterotrophic growth (Jia and Conrad 2009) might result in the dominant contribution of bacterial community to nitrification in our forest soils.

Moreover, this specific sensitivity of bacterial ammonia oxidizers might be associated with changes in the species composition of these bacteria (Isobe et al. 2020). While the overall compositions of bacterial and fungal communities in our forest soils were less sensitive to moderately elevated nitrogen deposition (Fig. 5), Isobe et al. [2020] found significant changes in the species composition of bacterial ammonia oxidizers along with forest slope gradients. Accordingly, Isobe et al. [2020] pointed out the importance of specific microbial community compositions in elucidating soil nitrogen dynamics under changing environmental conditions.

\subsection{Environmental factors vs. nitrogen deposition}

In our forest, there was little evidence indicating that environmental factors other than nitrogen deposition had caused the pseudo-correlation between nitrogen deposition and soil microbial properties. This was based on our findings that environmental factors such as soil water content and temperature were all similar between the forest edge and interior (Fig. 5). Additionally, soil pH was less correlated with the amount of nitrogen deposition (Table 1), while Urakawa et al. [2016] suggested that soil acidity would be a significant factor affecting nitrogen mineralization activity in Japanese Andosols. Thus, the moderately 
elevated nitrogen deposition in our forest might be insufficient to create a significant gradient of those environmental and soil physicochemical factors that can directly affect microbial properties. The situation indicating similar environmental and soil physicochemical factors between the forest interiors and edges was strictly different from the situations in previous studies in forests in Europe (Remy et al. 2016, 2017, 2018a, 2018b) and USA (Reinmann and Hutyra 2017), where not only nitrogen deposition but also other environmental and soil physicochemical factors have changed gradually from edge to interior.

\section{Conclusions}

In a Japanese cool-temperate forest surrounded by pasture grasslands, we found that soil microbial activities and their abundances increased along with spatial gradients of nitrogen deposition from forest interior to boundary edge area, but elevated levels of nitrogen deposition in the forest edges were moderate $\left(<10 \mathrm{~kg} \mathrm{~N} \mathrm{ha}^{-1}\right.$ year $\left.{ }^{-1}\right)$, rather than extreme $\left(>20 \mathrm{~kg} \mathrm{~N}^{-1} \mathrm{year}^{-1}\right)$. Our finding was different from most previous studies, which mainly focused on the effects of $>20 \mathrm{~kg} \mathrm{~N} \mathrm{ha}^{-1}$ year-1 nitrogen deposition and showed a reduction in soil organic matter decomposition and microbial $\mathrm{CO}_{2}$ release (Janssens et al. 2010; Jia et al. 2020; Zhang, Chen, and Ruan 2018). Because of the significant coverage of nitrogen-limited forest ecosystems (Groffman et al. 2018; McLauchlan et al. 2017; Reay et al. 2008) and the significant increase in fragmented forest ecosystems over the world (Haddad et al. 2015; Smith et al. 2018), understanding the responses of soil microbial communities to moderately elevated nitrogen deposition is essential, in order to capture reliable changes in carbon and nutrient cycles under changing environments. Through this study, we provided primary information on soil microbial response to moderately elevated nitrogen deposition.

\section{Declarations}

\section{Availability of data and material}

The Illumina datasets obtained in this study are available at NCBI (National Center for Biotechnology Information) Sequence Read Archive (SRA) under accession number PRJNA612411 (from SRX7906297 to SRX7906320 as the SRA experiment accession numbers). Other data that support the findings of this study are available from the corresponding author upon reasonable request. The codes that process the data of this study are also available from the corresponding author upon reasonable request.

\section{Competing interests}

The authors declare that they have no competing interest.

\section{Funding}

This work was supported by the Japan Society for the Promotion of Science (JSPS) KAKENHI (grant numbers 17H01868, 17K15286). 


\section{Authors' contributions}

$\mathrm{HN}, \mathrm{GK}, \mathrm{KF}, \mathrm{TY}, \mathrm{MW}$, and JK conceived and designed the study. HN, MN, GK, KF, TY, MW, JK, RT carried out all of the field works. KF, GK, and TK analyzed the throughfall water samples. HN, JK, and MA analyzed soil physicochemical properties. $\mathrm{MN}$ and $\mathrm{KF}$ measure the net nitrification and nitrogen mineralization rate of the soil sample. HN, MN, and TK analyzed soil microbial abundance and community structure. HN conducted the statistical analysis of the data and wrote the first version of the manuscript. All authors advised on the content and revised the manuscript. All authors have read and approved the final manuscript.

\section{Authors' information}

$\mathrm{HN}$ presently belongs to the Institute of Space-Earth and Environmental Research, Nagoya University, Nagoya, Aichi 464-8601, Japan.

\section{Acknowledgements}

This work was supported by the Japan Society for the Promotion of Science (JSPS) KAKENHI (grant numbers 17H01868, 17K15286). The authors thank Dr. Kazuya Kobayashi and technical staffs Mr. Yasuyuki Shibata, Mr. Tomoyuki Nakagawa, Mr. Jun Yanagimoto, Mr. Ken-ichi Ohta, Mr. Yuhei Nishioka, Mr. Yasunori Kishimoto, Mr. Yuta Miyagi, and Mr. Shuichi Sato, in the Shibecha branch of the Hokkaido Forest Research Station, Field Science Education and Research Center, Kyoto University, and Dr. Yuki Kamidaira of the Japan Atomic Energy Agency (JAEA) for support with the fieldwork; Ms. Misuzu Kaminaga, Ms. Kikuko Yoshigaki, and Mr. Taro Ishii of JAEA for support with the laboratory work; Ms. Chikako Okabe of the Ibaraki University for support with the chemical analyses of throughfall samples; Dr. Akinari Yokoya and Ms. Eri Hirose of the National Institutes for Quantum and Radiological Science and Technology for usage of the Real-Time PCR System; and Dr. Hirochika Naganawa and Dr. Hiroyuki Okamura of JAEA for usage of the DNA analyzing instruments.

\section{References}

Abarenkov K, Nilsson RH, Larsson KH, et al. 2010: The UNITE database for molecular identification of fungi - recent updates and future perspectives. New Phytol., 186, 281-285.

https://nph.onlinelibrary.wiley.com/doi/full/10.1111/j.1469-8137.2009.03160.x (October, 2020).

Allison SD, LeBauer DS, Ofrecio MR, Reyes R, Ta AM, Tran TM 2009: Low levels of nitrogen addition stimulate decomposition by boreal forest fungi. Soil Biol. Biochem., 41, 293-302. http://dx.doi.org/10.1016/j.soilbio.2008.10.032.

Bobbink R, Hicks K, Galloway J, et al. 2010: Global assessment of nitrogen deposition effects on terrestrial plant diversity: a synthesis. (Special Issue: Perspectives on the modern nitrogen cycle.). Ecol. Appl., 20, 30-59. http://www.esajournals.org/doi/abs/10.1890/08-

1140.1;\%5Cnhttp://sfx.kb.dk.ep.fjernadgang.kb.dk/sfx_local? 
sid=OVID:cabadb\&id=pmid:\&id=doi:10.1890\%2F08-1140.1\&issn=1051-

$0761 \&$ isbn $=\&$ volume=20\&issue $=1 \&$ spage=30\&pages $=30-59 \&$ date $=2010 \&$ title=Ecological + Application .

Butterbach-Bahl K, Willibald G, Papen H 2002: Soil core method for direct simultaneous determination of N2 and N2O emissions from forest soils. Plant Soil, 240, 105-116.

Caporaso JG, Kuczynski J, Stombaugh J, et al. 2010: QIIME allows analysis of high-throughput community sequencing data. Nat. Methods, 7, 335-336.

https://www.ncbi.nlm.nih.gov/pmc/articles/PMC3156573/ (October, 2020).

Chiwa M, Inoue S, Tashiro N, Ohgi D, Uehara Y, Shibata H, Kume A 2015: Assessing the role of forests in mitigating eutrophication downstream of pasture during spring snowmelt. Hydrol. Process., 29, 615-623.

Chiwa M, Tateno R, Hishi T, Shibata H 2018: Nitrate leaching from Japanese temperate forest ecosystems in response to elevated atmospheric $\mathrm{N}$ deposition. J. For. Res., 00, 1-15.

https://www.tandfonline.com/doi/full/10.1080/13416979.2018.1530082.

Christopher SF, Shibata H, Ozawa M, Nakagawa Y, Mitchell MJ 2008: The effect of soil freezing on N cycling: Comparison of two headwater subcatchments with different vegetation and snowpack conditions in the northern Hokkaido Island of Japan. Biogeochemistry, 88, 15-30.

Decina SM, Hutyra LR, Templer PH 2019: Hotspots of nitrogen deposition in the world's urban areas: a global data synthesis. Front. Ecol. Environ., fee.2143.

https://onlinelibrary.wiley.com/doi/abs/10.1002/fee.2143.

Dentener F, Drevet J, Lamarque JF, et al. 2006: Nitrogen and sulfur deposition on regional and global scales: A multimodel evaluation. Global Biogeochem. Cycles, 20.

Galloway JN, Dentener FJ, Capone DG, et al. 2004: Nitrogen cycles: Past, present, and future. Biogeochemistry, 70, 153-226.

Gilliam FS, Burns DA, Driscoll CT, Frey SD, Lovett GM, Watmough SA 2019: Decreased atmospheric nitrogen deposition in eastern North America: Predicted responses of forest ecosystems. Environ. Pollut., 244, 560-574. https://www.sciencedirect.com/science/article/pii/S0269749118325983 (January, 2019).

Groffman PM, Driscoll CT, Durán J, et al. 2018: Nitrogen oligotrophication in northern hardwood forests. Biogeochemistry, 141, 523-539.

Haddad NM, Brudvig LA, Clobert J, et al. 2015: Habitat fragmentation and its lasting impact on Earth's ecosystems. Sci. Adv., 1, e1500052.

http://advances.sciencemag.org/lookup/doi/10.1126/sciadv.1500052 (June, 2019).

Haney RL, Brinton WH, Evans E 2008: Estimating soil carbon, nitrogen, and phosphorus mineralization from short-term carbon dioxide respiration. Commun. Soil Sci. Plant Anal., 39, 2706-2720. 
https://www.tandfonline.com/doi/abs/10.1080/00103620802358862 (January, 2021).

Hayashi K, Yan X 2010: Airborne nitrogen load in Japanese and Chinese agroecosystems. Soil Sci. Plant Nutr., 56, 2-18. http://www.tandfonline.com/doi/abs/10.1111/j.1747-0765.2009.00423.x (January, 2021).

Hosokawa N, Isobe K, Urakawa R, Tateno R, Fukuzawa K, Watanabe T, Shibata H 2017: Soil freeze-thaw with root litter alters $\mathrm{N}$ transformations during the dormant season in soils under two temperate forests in northern Japan. Soil Biol. Biochem., 114, 270-278.

https://www.sciencedirect.com/science/article/pii/S0038071717301190 (April, 2018).

IPCC (Intergovernmental Panel on Climate Change) 2013: Climate Change 2013: The Physical Science Basis. Contribution of Working Group I to the Fifth Assessment Report of the Intergovernmental Panel on Climate Change. Climate Change 2013: The Physical Science Basis. Contribution of Working Group I to the Fifth Assessment Report of the Intergovernmental Panel on Climate Change (TF Stocker, D Qin, G-K Plattner, et al. Eds.). Cambridge University Press: Cambridge, United Kingdom and New York, NY, USA. http://www.climatechange2013.org/images/report/WG1AR5_ALL_FINAL.pdf.

Isobe K, Ise Y, Kato H, Oda T, Vincenot CE, Koba K, Tateno R, Senoo K, Ohte N 2020: Consequences of microbial diversity in forest nitrogen cycling: diverse ammonifiers and specialized ammonia oxidizers. ISME J., 14, 12-25. http://dx.doi.org/10.1038/s41396-019-0500-2.

Isobe K, Oka H, Watanabe T, Tateno R, Urakawa R, Liang C, Senoo K, Shibata H 2018: High soil microbial activity in the winter season enhances nitrogen cycling in a cool-temperate deciduous forest. Soil Biol. Biochem., 124, 90-100. https://doi.org/10.1016/j.soilbio.2018.05.028.

IUSS Working Group WRB 2015: World Reference Base for Soil Resources 2014, update 2015 International soil classification system for naming soils and creating legends for soil maps. World Reference Base for Soil Resources 2014, update 2015 International soil classification system for naming soils and creating legends for soil maps., World Soil. FAO, Rome.

Janssens IA, Dieleman W, Luyssaert S, et al. 2010: Reduction of forest soil respiration in response to nitrogen deposition. Nat. Geosci., 3, 315-322. http://dx.doi.org/10.1038/ngeo844.

Jassal RS, Black TA, Roy R, Ethier G 2011: Effect of nitrogen fertilization on soil CH4 and N2O fluxes, and soil and bole respiration. Geoderma, 162, 182-186. http://dx.doi.org/10.1016/j.geoderma.2011.02.002 (February, 2020).

Jia X, Zhong Y, Liu J, Zhu G, Shangguan Z, Yan W 2020: Effects of nitrogen enrichment on soil microbial characteristics: From biomass to enzyme activities. Geoderma, 366.

Jia Z, Conrad R 2009: Bacteria rather than Archaea dominate microbial ammonia oxidation in an agricultural soil. Environ. Microbiol., 11, 1658-1671. 
Kanakidou M, Myriokefalitakis S, Daskalakis N, Fanourgakis G, Nenes A, Baker AR, Tsigaridis K, Mihalopoulos N 2016: Past, present, and future atmospheric nitrogen deposition. J. Atmos. Sci., 73, 2039-2047. http://journals.ametsoc.org/doi/10.1175/JAS-D-15-0278.1 (January, 2020).

Koarashi J, Atarashi-Andoh M, Takeuchi E, Nishimura S 2015: Topographic heterogeneity effect on the accumulation of Fukushima-derived radiocesium on forest floor driven by biologically mediated processes. Sci. Rep., 4, 6853. http://www.nature.com/articles/srep06853 (December, 2018).

Koarashi J, Nishimura S, Atarashi-Andoh M, Matsunaga T, Sato T, Nagao S 2018: Radiocesium distribution in aggregate-size fractions of cropland and forest soils affected by the Fukushima nuclear accident. Chemosphere, 205, 147-155. https://ac.els-cdn.com/S0045653518307410/1-s2.0S0045653518307410-main.pdf?_tid=a9a10763-d3ed-4723-8efa5c716e746715\&acdnat=1525679152_96dbfcd396c99599aff19d14ab971bb2 (May, 2018).

Kramer MG, Lajtha K, Aufdenkampe AK 2017: Depth trends of soil organic matter C:N and 15N natural abundance controlled by association with minerals. Biogeochemistry, 136, 237-248. http://link.springer.com/10.1007/s10533-017-0378-x.

Leininger S, Urich T, Schloter M, Schwark L, Qi J, Nicol GW, Prosser JI, Schuster SC, Schleper C 2006: Archaea predominate among ammonia-oxidizing prokaryotes in soils. Nature, 442, 806-809. http://www.nature.com/articles/nature04983 (November, 2019).

Li W, Fu L, Niu B, Wu S, Wooley J 2012: Ultrafast clustering algorithms for metagenomic sequence analysis. Brief. Bioinform., 13, 656-668. https://academic.oup.com/bib/articlelookup/doi/10.1093/bib/bbs035 (December, 2017).

McLauchlan KK, Gerhart LM, Battles JJ, et al. 2017: Centennial-scale reductions in nitrogen availability in temperate forests of the United States. Sci. Rep., 7, 1-7. http://dx.doi.org/10.1038/s41598-017-08170-z.

Nakayama M, Imamura S, Taniguchi T, Tateno R 2019: Does conversion from natural forest to plantation affect fungal and bacterial biodiversity, community structure, and co-occurrence networks in the organic horizon and mineral soil? For. Ecol. Manage.

Nakayama M, Tateno R 2018: Solar radiation strongly influences the quantity of forest tree root exudates. Trees - Struct. Funct., 32, 871-879. http://dx.doi.org/10.1007/s00468-018-1685-0.

Network Center for EANET 2021: EANET Data on the Acid Deposition in the East Asian Region. https://monitoring.eanet.asia/document/public/index (January, 2021).

Niu S, Classen AT, Dukes JS, et al. 2016: Global patterns and substrate-based mechanisms of the terrestrial nitrogen cycle. Ecol. Lett., 19, 697-709.

Nordin A, Strengbom J, Witzell J, Nasholm T, Ericson L 2005: Nitrogen deposition and the biodiversity of boreal forests: Implications for the nitrogen critical load. Ambio, 34, 20-24. 
Oksanen JFG, Guillaume Blanchet F, Friendly M, et al. 2018: Vegan: community ecology package. http://cran.r-project.org/package=vegan\%0Ahttp://cran.rproject.org/package vegan.

R Core Team 2017: R: A Language and Environment for Statistical Computing. https://www.r-project.org/.

Reay DS, Dentener F, Smith P, Grace J, Feely RA 2008: Global nitrogen deposition and carbon sinks. Nat. Geosci., 1, 430-437.

Reinmann AB, Hutyra LR 2017: Edge effects enhance carbon uptake and its vulnerability to climate change in temperate broadleaf forests. Proc. Natl. Acad. Sci., 114, 107-112.

http://www.pnas.org/lookup/doi/10.1073/pnas.1612369114.

Remy E, Gasche R, Kiese R, Wuyts K, Verheyen K, Boeckx P 2017: Edge effects on $\mathrm{N}_{2} \mathrm{O}$, $\mathrm{NO}$ and $\mathrm{CH}_{4}$ fluxes in two temperate forests. Sci. Total Environ., 575, 1150-1155.

https://linkinghub.elsevier.com/retrieve/pii/S0048969716321271 (November, 2018).

Remy E, Wuyts K, Boeckx P, et al. 2016: Strong gradients in nitrogen and carbon stocks at temperate forest edges. For. Ecol. Manage., 376, 45-58.

https://www.sciencedirect.com/science/article/pii/S0378112716302870?via\%3Dihub (November, 2018).

Remy E, Wuyts K, Van Nevel L, De Smedt P, Boeckx P, Verheyen K 2018: Driving Factors Behind Litter Decomposition and Nutrient Release at Temperate Forest Edges. Ecosystems, 21, 755-771. http://link.springer.com/10.1007/s10021-017-0182-4 (November, 2018).

Remy E, Wuyts K, Verheyen K, Gundersen P, Boeckx P 2018: Altered microbial communities and nitrogen availability in temperate forest edges. Soil Biol. Biochem., 116, 179-188.

https://doi.org/10.1016/j.soilbio.2017.10.016.

Rotthauwe JH, Witzel KP, Liesack W 1997: The ammonia monooxygenase structural gene amoa as a functional marker: Molecular fine-scale analysis of natural ammonia-oxidizing populations. Appl. Environ. Microbiol., 63, 4704-4712.

Rustad L, Campbell J, Marion G, Norby R, Mitchell M, Hartley A, Cornelissen J, Gurevitch J 2001: A metaanalysis of the response of soil respiration, net nitrogen mineralization, and aboveground plant growth to experimental ecosystem warming. Oecologia, 126, 543-562. https://www.jstor.org/stable/4222885? seq=1 (January, 2021).

Schwede DB, Simpson D, Tan J, Fu JS, Dentener F, Du E, deVries W 2018: Spatial variation of modelled total, dry and wet nitrogen deposition to forests at global scale. Environ. Pollut., 243, 1287-1301. /pmc/articles/PMC7050289/?report=abstract (October, 2020).

Smith IA, Hutyra LR, Reinmann AB, Marrs JK, Thompson JR 2018: Piecing together the fragments: elucidating edge effects on forest carbon dynamics. Front. Ecol. Environ., 16, 213-221. 
http://doi.wiley.com/10.1002/fee.1793 (April, 2019).

Smith KA, Dobbie KE, Ball BC, et al. 2000: Oxidation of atmospheric methane in Northern European soils, comparison with other ecosystems, and uncertainties in the global terrestrial sink. Glob. Chang. Biol., 6 , 791-803. http://doi.wiley.com/10.1046/j.1365-2486.2000.00356.x (February, 2020).

Strickland MS, Rousk J 2010: Considering fungal: Bacterial dominance in soils - Methods, controls, and ecosystem implications. Soil Biol. Biochem., 42, 1385-1395.

http://dx.doi.org/10.1016/j.soilbio.2010.05.007.

Tateno R, Imada S, Watanabe T, Fukuzawa K, Shibata H 2019: Reduced snow cover changes nitrogen use in canopy and understory vegetation during the subsequent growing season. Plant Soil, 438, 157-172. http://link.springer.com/10.1007/s11104-019-04011-2 (March, 2020).

Tian D, Jiang L, Ma S, et al. 2017: Effects of nitrogen deposition on soil microbial communities in temperate and subtropical forests in China. Sci. Total Environ., 607-608, 1367-1375.

http://dx.doi.org/10.1016/j.scitotenv.2017.06.057.

Tourna M, Freitag TE, Nicol GW, Prosser JI 2008: Growth, activity and temperature responses of ammonia-oxidizing archaea and bacteria in soil microcosms. Environ. Microbiol., 10, 1357-1364. http://doi.wiley.com/10.1111/j.1462-2920.2007.01563.x (January, 2020).

Urakawa R, Ohte N, Shibata H, et al. 2016: Factors contributing to soil nitrogen mineralization and nitrification rates of forest soils in the Japanese archipelago. For. Ecol. Manage., 361, 382-396. http://dx.doi.org/10.1016/j.foreco.2015.11.033.

Urakawa R, Ohte N, Shibata H, et al. 2014: Biogeochemical nitrogen properties of forest soils in the Japanese archipelago. Ecol. Res., 30, 1-2. http://doi.wiley.com/10.1007/s11284-014-1212-8 (February, 2019).

Vance ED, Brookes PC, Jenkinson DS 1987: An extraction method for measuring soil microbial biomass C. Soil Biol. Biochem., 19, 703-707.

Waldner P, Marchetto A, Thimonier A, et al. 2014: Detection of temporal trends in atmospheric deposition of inorganic nitrogen and sulphate to forests in Europe. Atmos. Environ., 95, 363-374.

https://www.sciencedirect.com/science/article/pii/S1352231014005007?via\%3Dihub (October, 2020).

Waldrop MP, Zak DR, Sinsabaugh RL 2004: Microbial community response to nitrogen deposition in northern forest ecosystems. Soil Biol. Biochem., 36, 1443-1451.

Wang Q, Garrity GM, Tiedje JM, Cole JR 2007: Naïve Bayesian classifier for rapid assignment of rRNA sequences into the new bacterial taxonomy. Appl. Environ. Microbiol., 73, 5261-5267.

http://www.ncbi.nlm.nih.gov/pubmed/17586664 (February, 2018). 
Waud M, Busschaert P, Ruyters S, Jacquemyn H, Lievens B 2014: Impact of primer choice on characterization of orchid mycorrhizal communities using 454 pyrosequencing. Mol. Ecol. Resour., 14, 679-699. http://doi.wiley.com/10.1111/1755-0998.12229 (February, 2020).

Zak DR, Holmes WE, MacDonald NW, Pregitzer KS 1999: Soil Temperature, Matric Potential, and the Kinetics of Microbial Respiration and Nitrogen Mineralization. Soil Sci. Soc. Am. J., 63, 575-584. http://doi.wiley.com/10.2136/sssaj1999.03615995006300030021x (January, 2021).

Zhang T, Chen HYH, Ruan H 2018: Global negative effects of nitrogen deposition on soil microbes. ISME J., 12, 1817-1825. http://www.nature.com/articles/s41396-018-0096-y (January, 2020).

\section{Figures}



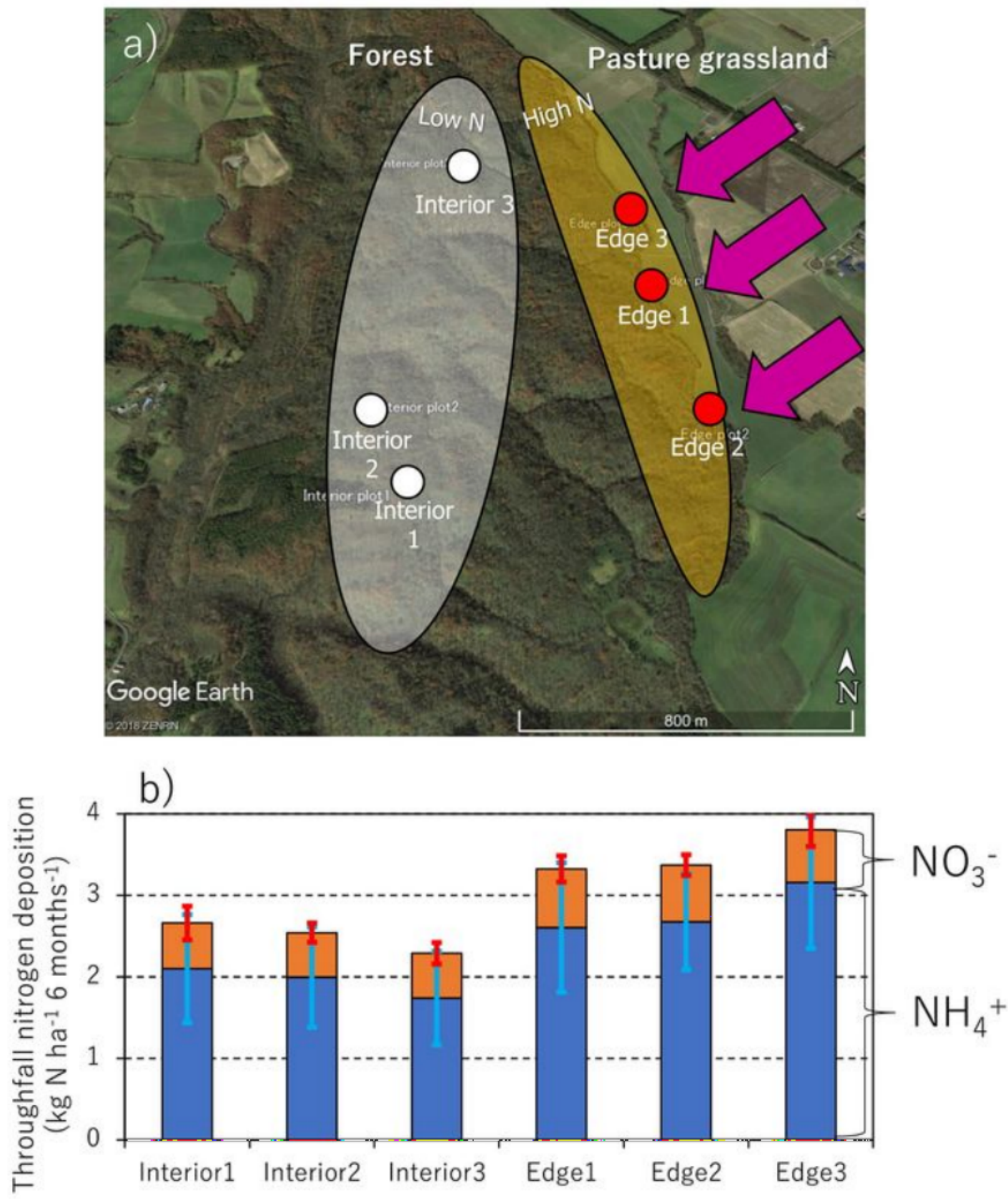

\section{Figure 1}

Locations of six experimental plots in a Japanese cool temperate forest (a), and nitrogen deposition via throughfall for 6 months (May 9th to November 20th, 2018) in each experimental plot (b). Purple arrows in the top panel represent major wind flow which transport fertilizer from pasture grasslands to our forest. Error bars in bottom panel represent standard deviations $(n=7)$. 


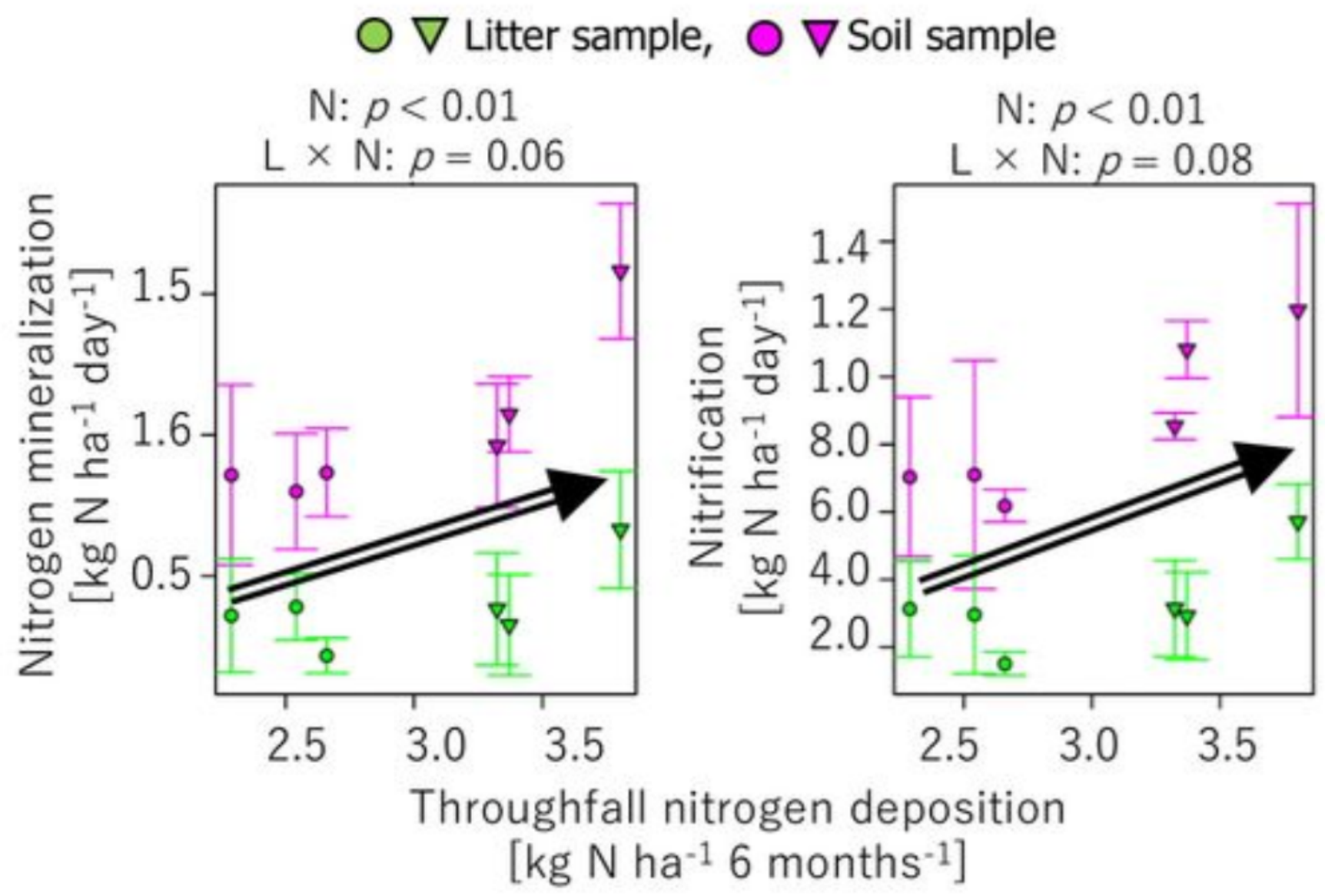

Figure 2

Correlations of net nitrogen mineralization and nitrification rates with nitrogen deposition. The probability level ( $p$ value) for statistical significance examined by two-way ANCOVA was presented above panels.

The two-way ANCOVA was applied to the correlation and the difference in correlations between litter and soil samples (see text for details). Arrows represent correlations with $p<0.05$. 

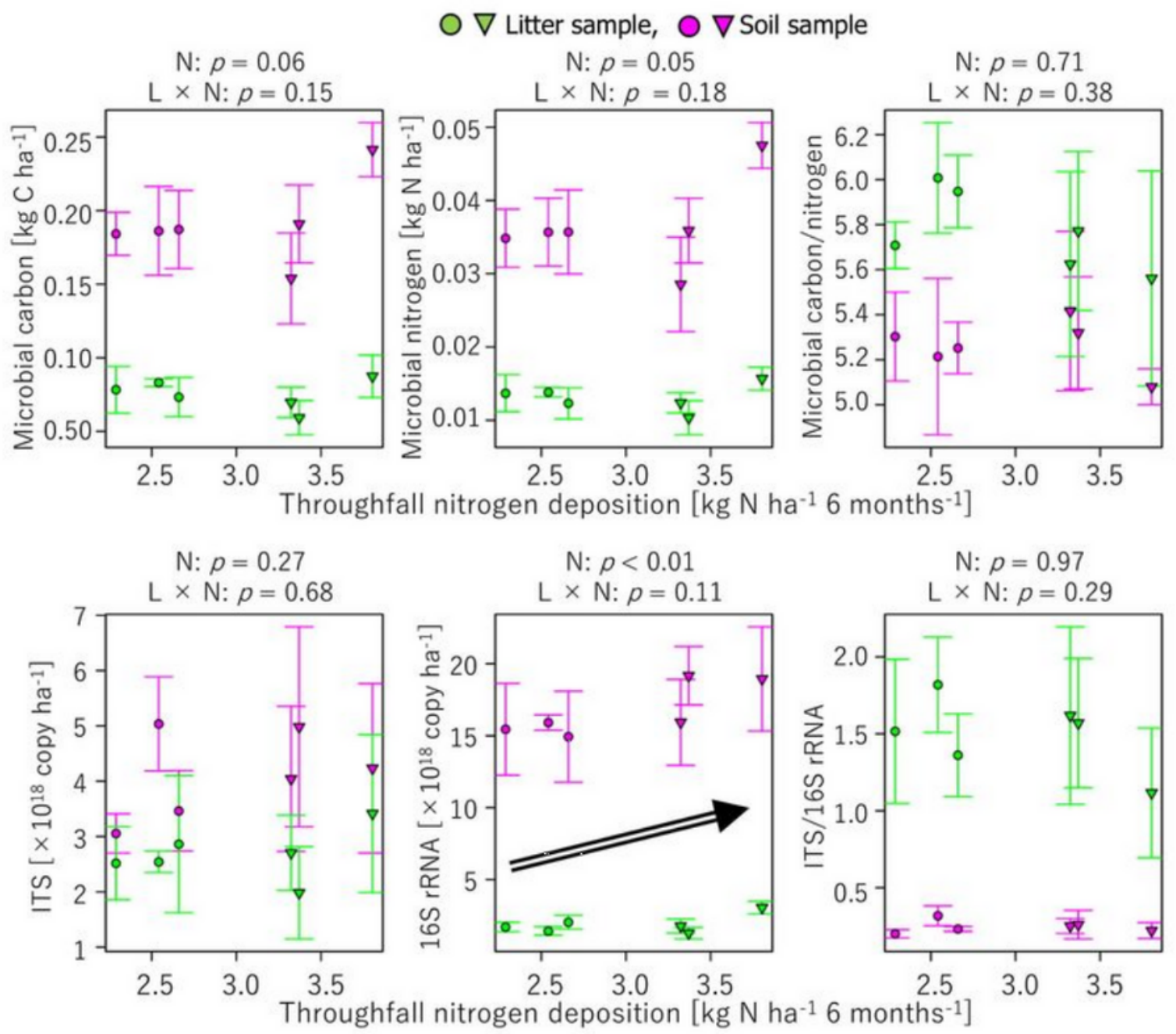

$\mathrm{N}: p<0.01$

$\mathrm{L} \times \mathrm{N}: p<0.01$

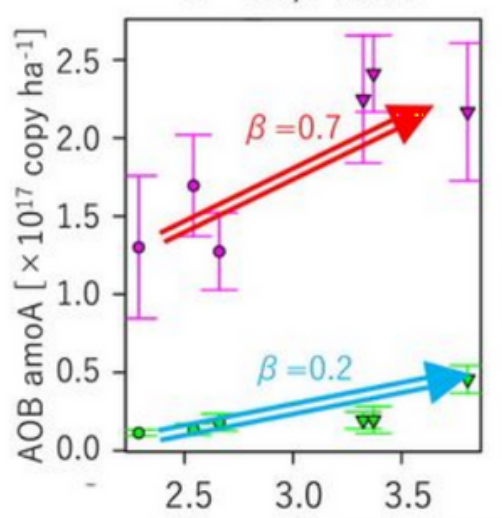

$\mathrm{N}: p=0.10$

$\mathrm{L} \times \mathrm{N}: p=0.26$

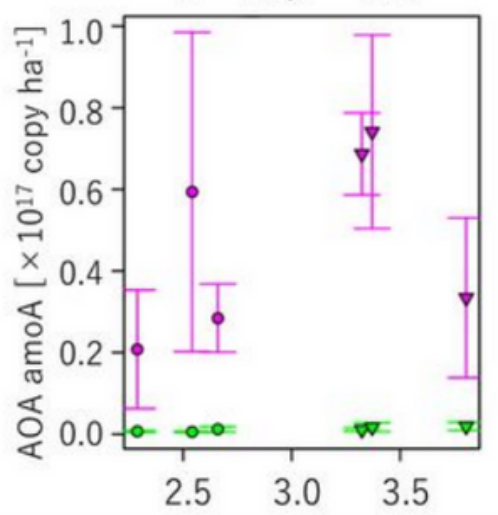

$\mathrm{N}: p=0.99$ $\mathrm{L} \times \mathrm{N}: p=0.99$

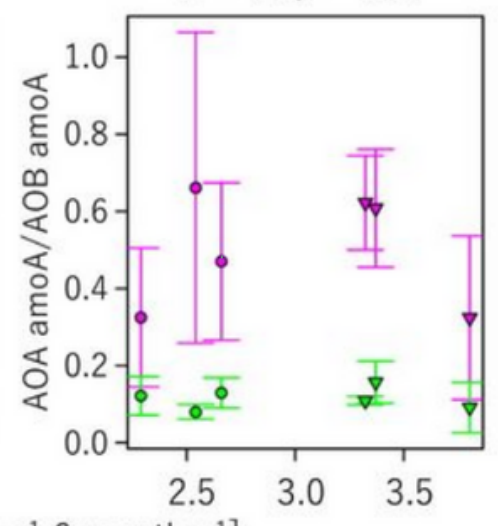

\section{Figure 3}

Correlations of microbial biomass carbon and nitrogen and various gene contents, such as bacterial $16 \mathrm{~S}$ rRNA, fungal ITS, and bacterial and archaeal amoA genes, with nitrogen deposition. Statistical analysis of correlation was conducted in the same manner as Figure 2 (see text for details). 


\section{perMANOVA:}

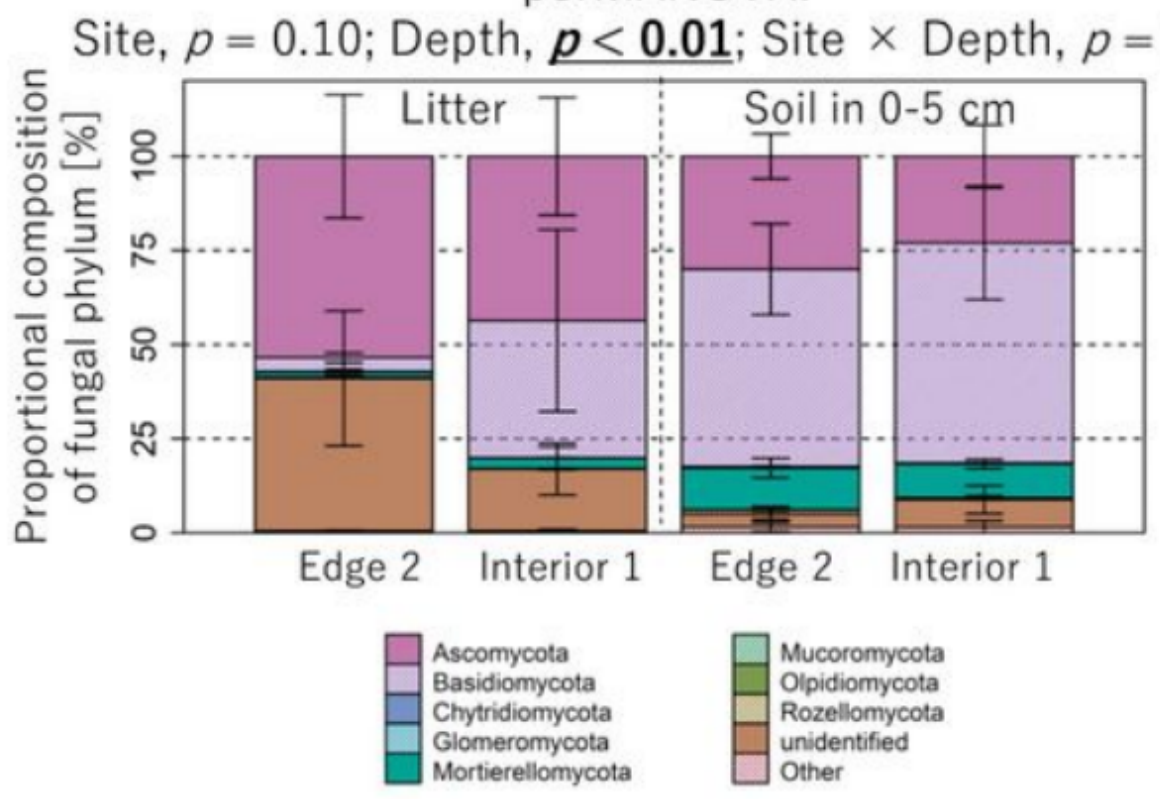

\section{perMANOVA:}

Site, $p=0.08$; Depth, $\underline{p<0.01}$; Site $\times$ Depth, $p=0.46$
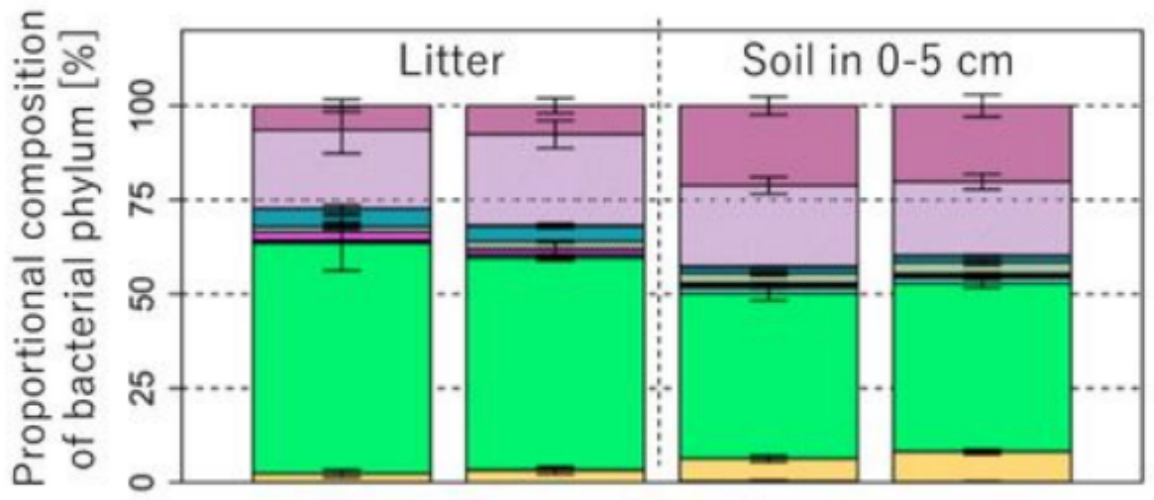

Edge 2 Interior $1 \quad$ Edge 2 Interior 1

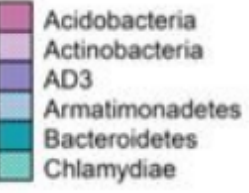

Actinobacteria

AD3

Bacteroidetes

Chlamydiae
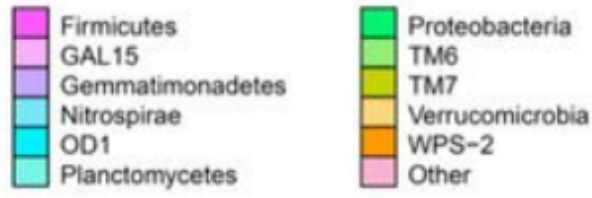

\section{Figure 4}

Comparison of fungal and bacterial community structures between Edge 2 and Interior 1 plots and between litter and soil layers. The probability level ( $p$ value) for statistical significance examined by perMANOVA was presented above panels. 
$\mathrm{O} \Delta$ Water content; $\mathrm{O} \Delta$ Temperature

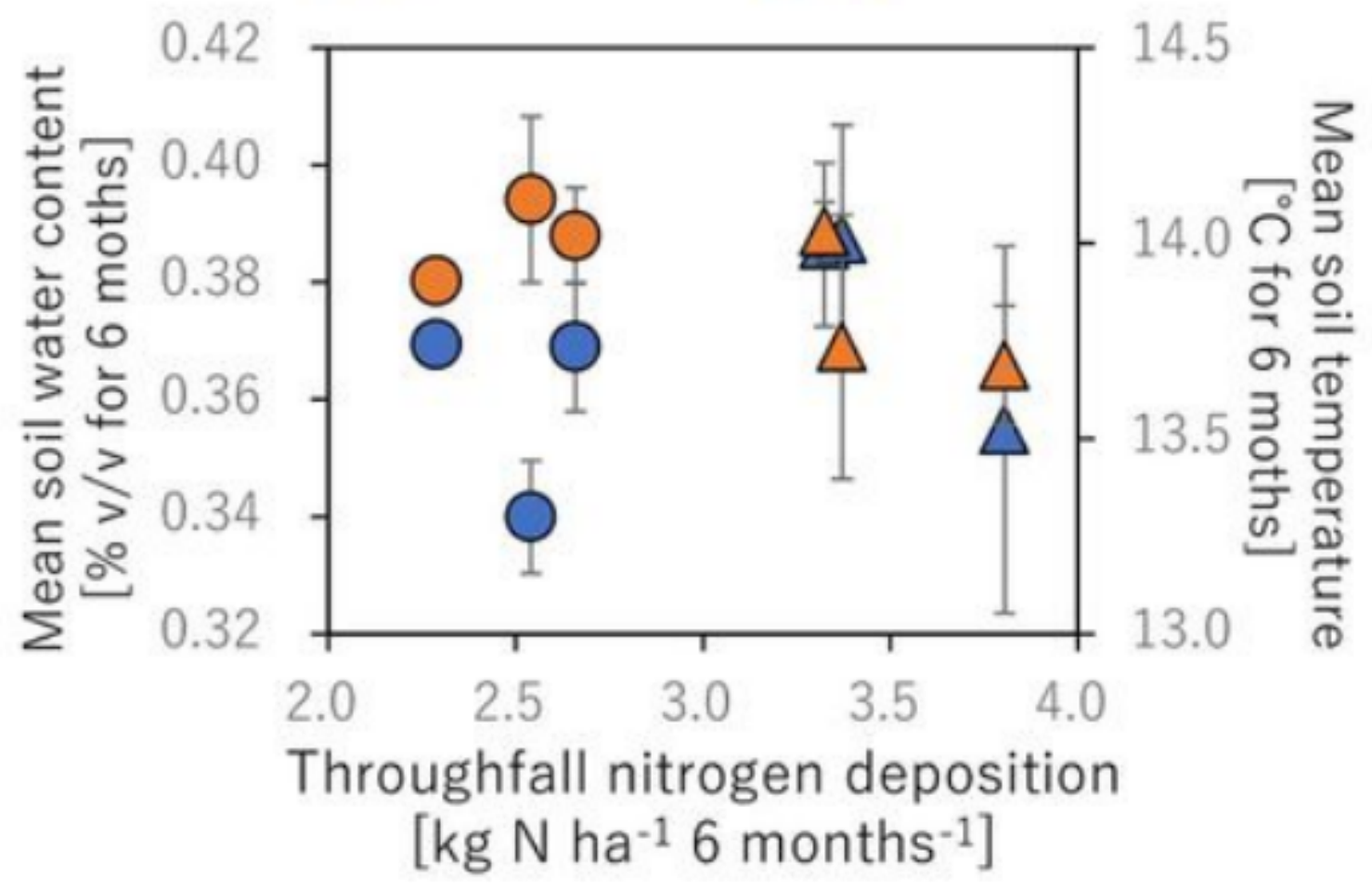

Figure 5

Correlations of soil water content and temperature with nitrogen deposition. The presented soil water content and temperature are seasonal means for the observation period from May to November 2018. No significant correlation was observed between nitrogen deposition and the environmental factors without any significant difference by t-test $(p>0.05)$.

\section{Supplementary Files}

This is a list of supplementary files associated with this preprint. Click to download.

- Graphicalabstracts200719.pdf

- TableS1200719.docx

- TableS2200719.docx 